PEDAGOGIA : Jurnal Ilmu Pendidikan

\title{
STUDI KEBIJAKAN PENDIDIKAN PROFESI GURU PENDIDIKAN ANAK USIA DINI
}

\author{
${ }^{1)}$ Rudiyanto, S.Pd, M.Si (Ketua) \\ ${ }^{1}$ Dosen Pada Program Studi Pendidikan Anak Usia Dini, Fakultas Ilmu Pendidikan \\ Universitas Pendidikan Indonesia \\ Email: rudiyanto1706@gmail.com \\ ${ }^{2}$ Rita Mariyana, M.Pd (Anggota) \\ ${ }^{1}$ Dosen Pada Program Studi Pendidikan Anak Usia Dini , Fakultas Ilmu Pendidikan \\ Universitas Pendidikan Indonesia \\ Email:ritamariyana@upi.edu \\ ${ }^{3)}$ Euis Kurniati, M.Pd (Anggota) \\ ${ }^{1}$ Dosen Pada Program Studi Pendidikan Anak Usia Dini, Fakultas Ilmu Pendidikan \\ Universitas Pendidikan Indonesia \\ Email: euis_kurniati@yahoo.com \\ ${ }^{4)}$ Ali Nugraha, M.Pd (Anggota) \\ Dosen Pada Program Studi Pendidikan Anak Usia Dini , Fakultas Ilmu Pendidikan \\ Universitas Pendidikan Indonesia \\ Email: alinugrah4@gmail.com
}

\begin{abstract}
Being a profes sional teacher is a continuous process that refers to the basic standard with continuous performance as sessment. The process of becoming a professional teacher pursued through academic education and professional education. This study aimed to describe the policy of professional education Early Childhood Education teachers to improve the professionalis mof early childhood teachers. The study uses descriptive analytical research methods with quantitative and qualitative approaches. The final product of this research is the teaching profession education programs that are designed based on the results of research proven and reliable.
\end{abstract}

Keywords: Professional, Teacher, Education, Early Childhood

\section{PENDAHULUAN}

Guru adalah pendidik profesional dengan tugas utama mendidik, mengajar, mengarahkan, melatih, menilai, dan mengevaluasi peserta didik pada pendidikan anak usia dini jalur pendidikan formal, pendidikan dasar, dan pendidikan menengah (PP 19 : 2005 pasal 1.1). "Teacher Is The Heart Of Quality Education." (Bahrul Hayat, 2005) Ungkapan ini mengisyaratkan bahwa guru merupakan salah satu indikator yang menentukan kualitas pendidikan. Bagus tidaknya kualitas pendidikan akan terlihat dari kinerja dan kompetensi guru sebagai pendidik yang melaksanakan proses pembelajaran.
Guru merupakan kunci keberhasilan pendidikan, dengan tugas profesionalnya, guru berfungsi membantu orang lain (peserta didik) untuk belajar dan berkembang; membantu perkembangan intelektual, personal dan sosial warga masyarakat yang memasuki sekolah (Cooper, 1982). Guru memotivasi siswa untuk belajar, disamping mengelola kelas secara efektif (Barry \& King, 1993). Untuk itu guru harus menjadi fasilitator belajar bagi peserta didik yang diwarnai secara kental oleh suasana warm and acceptance, realness, openess, prizing, trust, emphatic understanding, love, caring (Rogers, 1969; Gordon, 1974; Smith, 1978; Barry \&King, 1993; Hendrick, 1994). Guru harus selalu 
memperhatikan dan memahami suasana kelas dan menangani kelas secara sejuk, tidak meledak-ledak (Silberman, 1970), karena "language of acceptance is so powerfull" (Gordon, 1974). Sikap guru sangat berpengaruh terhadap tingkah laku dan kegiatan belajar siswa (Smith, 1978). Suasana kelas harus dibuat menjadi demokratis dengan pola hubungan "saya oke, kamu ok" (Beechhold, 1971) dalam (Prayitno, 2005)

Berdasarkan Standar Pendidik dalam Peraturan Pemerintah No. 19 Tahun 2005 disebutkan bahwa "Pendidik harus memiliki kualifikasi akademik dan kompetensi sebagai agen pembelajaran, sehat jasmani dan rohani, serta memiliki kemampuan untuk mewujudkan tujuan pendidikan nasional" yang meliputi :

1. Kualifikasi akademik pendidikan minimal diploma empat (D-IV) atau sarjana $(\mathrm{S} 1)$

2. Latar belakang pendidikan sesuai dengan bidang atau mata pelajaran yang diajarkan

3. Sertifikat profesi guru (minimal $36 \mathrm{SKS}$ di atas D-IV/S1)

Dalam Peraturan Pemerintah di atas, menyebutkan setidaknya terdapat empat kompetensi yang harus dimiliki guru sebagai pendidik, diantaranya :

1) Kompetensi Pedagogik, yaitu : "Kemampuan mengelola pembelajaran peserta didik yang meliputi pemahaman terhadap peserta didik, perancangan dan pelaksanaan pembelajaran, evaluasi hasil belajar, dan pengembangan peserta didik untuk mengaktualisasikan berbagai potensi yang dimilikinya."

2) Kompetensi Kepribadian yaitu : "Kepribadian pendidik yang mantap, stabil, dewasa, arif, dan berwibawa, menjadi teladan bagi peserta didik, dan berakhlak mulia."

3) Kompetensi Profesional, yaitu : "Kemampuan pendidik dalam penguasaan materi pembelajaran secara luas dan mendalam yang memungkinkannya membimbing peserta didik memperoleh kompetensi yang ditetapkan." dan

4) Kompetensi Sosial, yaitu : "Kemampuan pendidik berkomunikasi dan berinteraksi secara efektif dengan peserta didik, sesama pendidik, tenaga kependidikan, orangtua/wali peserta didik, dan masyarakat."

\section{LANDASAN TEORI}

\section{- Kompetensi Guru}

Istilah kompetensi (competence) dalam bahasa Indonesia diartikan sebagai kecakapan atau kemampuan. Terdapat beberapa makna dari kompetensi, diantaranya pendapat para ahli sebagai berikut.

1. "Teacher competency is the ability of a teacher to responsibility perform has or her duties appropriately". (Uzer Usman, 2000). Kemampuan seorang guru dalam melaksanakan kewajiban-kewajiban secara bertanggung jawab dan layak.

2. “...is a knowledge, skills, and abilities or capabilities that a person achieves, which become part of his or her being to the exent he or she can satisfactorily perform particular cognitive, afective, and psychomotor behaviors". (McAshan, 1981) dalam Mulyasa (2002). Kompetensi diartikan sebagai pengetahuan, ketrampilan dan kemampuan yang dikuasai oleh seseorang yang telah menjadi bagian dari dirinya, sehingga ia dapat melakukan perilaku-perilaku kognitif, afektif dan psikomotor dengan sebaik-baiknya.

3. Kompetensi adalah seperangkat pengetahuan, keterampilan dan perilaku yang harus dimiliki, dihayati, dan dikuasai oleh guru atau dosen dalam melaksanakan tugas kerpofesionalan. 
Guru merupakan jabatan atau profesi yang memerlukan keahlian khusus sebagai guru. Pekerjaan ini tidak dapat dilakukan oleh orang yang tidak memiliki keahlian untuk melakukan kegiatan atau pekerjaan sebagai guru. Untuk menjadi guru diperlukan syarat-syarat khusus, apalagi sebagai guru yang profesional harus menguasai betul seluk beluk pendidikan dengan berbagai ilmu pengetahuan lainnya yang perlu dibina dan dikembangkan melalui masa pendidikan tertentu atau pendidikan prajabatan (Usman, 2000:5). Dalam Kamus Besar Bahasa Indonesia, guru diartikan sebagai orang yang pekerjaannya mengajar. Akan tetapi pada pelaksanaanya dalam kegiatan pendidikan tugas guru tentunya bukan hanya mengajar yang berorientasi pada pengembangan kecakapan yang berdimensi ranah cipta saja akan tetapi guru turut juga mengembangkan ranah rasa dan karsa para peserta didik. Sebab, dalam perspektif psikologi pendidikan mengajar pada prinsipnya berarti proses perbuatan seseorang (guru) yang menjadikan orang lain (peserta didik) belajar, dalam arti mengubah seluruh dimensi perilakunya. (Syah, 1999:222). Sedangkan, menurut Surya (2003:134-135) ditinjau dari sudut pandang psikologis guru adalah sebagai : (1) pakar psikologi pendidikan, artinya seseorang yang memahami psikologi pendidikan dan mampu mengamalkannya dalam melaksanakan tugasnya sebagai pendidik;
(2) seniman dalam hubungan antar manusia (artist in human relations), artinya guru adalah orang yang memiliki kemampuan menciptakan suasana hubungan antar manusia khususnya dengan para siswa sehingga dapat mencapai tujuan pendidikan; (3) pembentuk kelompok (group builder), yaitu mampu menciptakan kelompok dan aktivitas-aktivitas untuk mencapai tujuan pendidikan; (4) catalytic agent atau inovator, yaitu orang yang mampu menciptakan suatu pembaharuan untuk membuat suatu hal yang lebih baik; dan (5) petugas kesehatan mental (mental hygiene worker), artinya guru bertanggung jawab bagi terciptanya kesehatan mental para siswa.

\section{METODE}

Untuk

menyelesaikan

suatu permasalahan pada suatu penelitian dituntut penyelidikan yang teratur, terencana, hatihati dan berkesinambungan. Sedangkan langkah-langkah yang harus dilakukan dalam menyelesaikan masalah suatu penelitian harus menggunakan metode penelitian.

Penelitian menggunakan metode deskriptif analitik dengan pendekatan kuantitatif dan kualitatif, hal ini dilakukan menyesuaikan dengan tujuan utama yang ingin dicapai yaitu mendeskripsikan, menganalisa dan menjelaskan secara menyeluruh dari data yang diperoleh sehingga dapat berlaku umum.

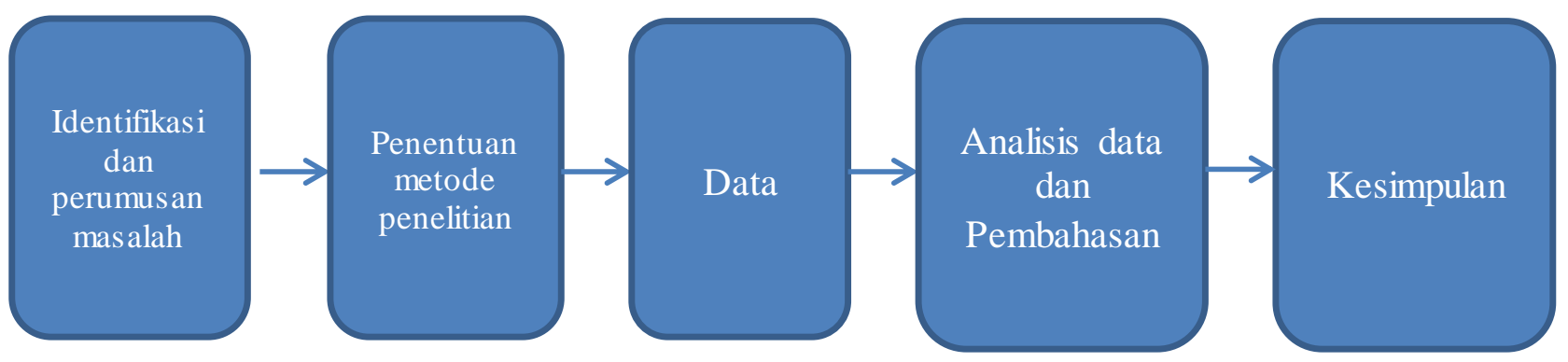




\section{Gambar 1. Alur Penelitian}

\section{HASIL DAN PEMBAHASAN}

\section{Kajian Kebijakan Pendidikan Profesi Guru}

Peraturan Pemerintah No. 74 Tahun 2008 tentang Guru telah menggariskan bahwa penyediaan guru menjadi kewenangan lembaga pendidikan tenaga kependidikan, yang selanjutnya dapat disebut sebagai penyediaan guru berbasis perguruan tinggi. Menurut produk hukum ini, lembaga pendidikan tenaga kependidikan adalah perguruan tinggi yang diberi tugas oleh pemerintah untuk menyelenggarakan program pengadaan guru pada pendidikan anak usia dini jalur pendidikan formal, pendidikan dasar, dan/atau pendidikan menengah, serta untuk menyelenggarakan dan mengembangkan ilmu kependidikan dan nonkependidikan. Guru harus memiliki kualifikasi akademik sekurang-kurangnya S1/D-IV dan bersertifikat pendidik. Jika seorang guru telah memiliki keduanya, statusnya diakui oleh negara sebagai guru profesional. UU No. 14 Tahun 2005 tentang Guru dan Dosen maupun PP No. 74 tentang Guru, telah mengamanatkan bahwa hanya guru yang berkualifikasi S1/D-IV bidang kependidikan dan non kependidikan saja yang memenuhi syarat sebagai guru. Itu pun jika mereka telah menempuh dan dinyatakan lulus pendidikan profesi.

Dua produk hukum tersebut menggariskan bahwa peserta pendidikan profesi ditetapkan oleh menteri, yang sangat mungkin didasari atas kuota kebutuhan formasi. Khusus untuk pendidikan profesi guru, beberapa amanat penting yang dapat disadap dari dua produk hukum ini. Pertama, calon peserta pendidikan profesi berkualifikasi S1/D-IV. Kedua, sertifikat pendidik bagi guru diperoleh melalui program pendidikan profesi yang diselenggarakan oleh perguruan tinggi yang memiliki program pengadaan tenaga kependidikan yang terakreditasi, baik yang diselenggarakan oleh pemerintah maupun masyarakat, dan ditetapkan oleh pemerintah. Ketiga, sertifikasi pendidik bagi calon guru harus dilakukan secara objektif, transparan, dan akuntabel. Keempat, jumlah peserta didik program pendidikan profesi setiap tahun ditetapkan oleh Menteri. Kelima, program pendidikan profesi diakhiri dengan uji kompetensi pendidik. Keenam, uji kompetensi pendidik dilakukan melalui ujian tertulis dan ujian kinerja sesuai dengan standar kompetensi. Ketujuh, ujian tertulis dilaksanakan secara komprehensif yang mencakup penguasaan: (1) wawasan atau landasan kependidikan, pemahaman terhadap peserta didik, pengembangan kurikulum atau silabus, perancangan pembelajaran, dan evaluasi hasil belajar; (2) materi pelajaran secara luas dan mendalam sesuai dengan standar isi mata pelajaran, kelompok mata pelajaran, dan/atau program yang diampunya; dan (3) konsep-konsep disiplin keilmuan, teknologi, atau seni yang secara konseptual menaungi materi pelajaran, kelompok mata pelajaran, dan/atau program yang diampunya. Kedelapan, ujian kinerja dilaksanakan secara holistik dalam bentuk ujian praktik

\section{Desain Pendidikan Profesionalisme Guru}

Kartadinata, S (2014:202) berpendapat bahwa kerangka pikir Pendidikan Profesi Guru sebagai ruh profesionalisasi pendidik ditandai dengan adanya bidang layanan ahli yang unik, yang diakui oleh masyarakat dan pemerintah, diperlukan pendidikan yang 
relatif lama dan sungguh-sungguh untuk menguasai the scientific basis of the arts dari layanan unik itu, latihan yang sistematis dan terawasi dalam proses latihan untuk menerapkan arts secara non rutin dan kontekstual di bawah supervisi profesional, imbalan yang layak, diikuti dengan tanggung jawab peningkatan profesionalitas secara berkelanjutan.

Berdasarkan Pada Konferensi Internasional Pendidikan Guru yang dilaksanakan pada bulan April 2010 di Universitas Pendidikan Indonesia tidak lagi mempersoalkan pendekatan konkuren dan konsekutif tapi lebih mengedepankan pendekatan koherensi konseptual-struktural dalam program dan penyelenggaraan pendidikan guru. Pemikiran utuh tentang penyelenggaraan Pendidikan Profesional Guru yang di dalamnya melumatkan persoalan-persoalan yuridis-akademik dan pendekatan pendidikan Guru yang dalam waktu berkepanjangan diperdebatkan diwujudkan UPI dalam konsep Re-desain Pendidikan Guru. Pendidikan Profesional Guru adalah sebuah keutuhan proses, mulai dari rekrutmen calon mahasiswa sampai pada uji kompetensi. Sebagaimana ditegaskan bahwa Pendidikan Profesional Guru mencakup pendidikan akademik dan pendidikan profesi sebagai keutuhan.

Beberapa alasan Pentingnya dilakukannya Re-Desain pendidikan Profesional guru.Pertama, memenuhi tuntutan Undang-undang Nomor 14 Tahun 2005 tentang Guru dan Dosen yang menegaskan guru sebagai sebuah profesi dengan sejumlah kompetensi yang dipersyaratkannya beserta hak yang melekat kepada para penyandangnya. Kedua, memenuhi tuntutan tentang perlunya peningkatankualitas guru melalui pengokohan content knowledge yang dilakukan secara seimbang dengan penguatan pedagogical knowledge serta pemberian pengalaman praktik mengajar dalam seting otentik.

Bertolak pada asumsi bahwa menjadi guru profesional adalah sebuah proses berkesinambungan yang mengacu kepada standar yang baku dengan penilaian kinerja secara terus menerus. Proses menjadi guru profesional ditempuh melalui pendidikan akademik dan pendidikan profesi. Proses tersebut bermuara pada peningkatan pengetahuan dan keterampilan mengajar melalui tiga hal berikut: (1) transfer pengalaman mengajar dalam seting otentik, (2) pemaduan teori dan praktik learning to teach dalam konteks practice in practice dan (3) berlangsung secara kolaboratif di dalam komunitas profesional.

\section{Rancangan Kompetensi Lulusan PPG PAUD UPI}

PP No. 74 Tahun 2005 tentang Guru mengamanatkan bahwa pembinaan dan pengembangan profesi guru meliputi pembinaan kompetensi pedagogik, kepribadian, sosial, dan profesional. Pembinaan dan pengembangan profesi guru sebagaimana dimaksud dilakukan melalui program pembinaan dan pengembangan profesi yang dalam hal ini adalah Pendidikan Profesi Guru. Program ini berfokus pada empat kompetensi di atas. Namun demikian, berdasarkan studi kebutuhan guru di lapangan, kebutuhan esensi pembinaan profesi beragam sifatnya. Kebutuhan dimaksud dikelompokkan ke dalam lima kategori, yaitu pemahaman tentang konteks pembelajaran, penguatan penguasaan materi, pengembangan metode mengajar, inovasi pembelajaran, dan pengalaman tentang teori-teori terkini. Hasil analisis kebutuhan dirumuskan dan dietakan dalam rancangan kompetensi lulusan PPG PAUD sebagai berikut; 
Tabel 1. Kompetensi Lulus an PPG PAUD UPI

\begin{tabular}{|c|c|c|}
\hline NO & KOMPETENSI & SUB KOMPETENSI \\
\hline 1 & $\begin{array}{l}\text { Mampu mengembangkan } \\
\text { kurikulum }\end{array}$ & $\begin{array}{l}\text { 1.1. Memilih materi pembelajaran yang sesuai } \\
\text { dengan tingkat perkembangan anak } \\
\text { 1.2. Menerapkan model pengembangan pembelajran } \\
\text { bagi anak usia dini } \\
\text { 1.3. Menyusun program pembelajaran secara } \\
\text { terpadu, kontekstual dan bermakna sesuai } \\
\text { dengan tingkat perkembangan anak }\end{array}$ \\
\hline 2 & $\begin{array}{l}\text { Mampu mengembangkan } \\
\text { perencanaan pembelajaran }\end{array}$ & $\begin{array}{l}\text { 2.1. Menyusun rancangan pembelajaran secara } \\
\text { lengkap, terpadu untuk berbagai kelompok usia } \\
\text { dan lembaga. } \\
\text { 2.2. Menyusun bahan pembelajaran berdasarkan } \\
\text { tema } \\
\text { 2.3. Membuat media pembelajaran } \\
\text { 2.4. Menyusun skenario pembelajaran } \\
\text { 2.5. Mengembangkan instrumen penilaian dan } \\
\text { evaluasi proses serta hasil belajar }\end{array}$ \\
\hline 3 & $\begin{array}{l}\text { Mampu } \\
\text { menyelenggarakan } \\
\text { pembelajaran yang } \\
\text { mendidik }\end{array}$ & $\begin{array}{l}\text { 3.1. Memanfaatkan teknologi informasi dan } \\
\text { komunikasi } \\
\text { 3.2. Menata lingkungan belajar yang aman, nyaman } \\
\text { dan menyenangkan untuk memfasilitasi proses } \\
\text { pembelajaran } \\
\text { 3.3. Menyelenggarakan pembelajaran melalui } \\
\text { bermain yang menstimulasi perkembangan anak } \\
\text { secara terpadu sesuai dengan perkembangan }\end{array}$ \\
\hline 4 & $\begin{array}{l}\text { Mampu melaksanakan } \\
\text { penilaian pembelajaran }\end{array}$ & $\begin{array}{l}\text { 4.1. Melakukan evaluasi proses dan hasil belajar } \\
\text { 4.2. Menganalisis hasil penilaian } \\
\text { 4.3. Mendokumentasikan hasil penilaian } \\
\text { 4.4. Menggunakan informasi hasil penilaian dan } \\
\text { evaluasi untuk merancang program stimulasi } \\
\text { perkembangan } \\
\text { 4.5. Mengkomunikasikan hasil penilaian dan } \\
\text { evaluasi kepada stake holder }\end{array}$ \\
\hline 5 & $\begin{array}{l}\text { Mampu mengembangkan } \\
\text { kualitas pembelajaran } \\
\text { secara berkelanjutan }\end{array}$ & $\begin{array}{l}\text { 5.1. Melakukan refleksi terhadap pembelajaran yang } \\
\text { telah dilaksanakan } \\
\text { 5.2. Memanfaatkan hasil refleksi utuk } \\
\text { pengembangan kegiatan pembelajaran }\end{array}$ \\
\hline 7 & $\begin{array}{l}\text { Memiliki sikap dan } \\
\text { perilaku sebagai guru } \\
\text { PAUD }\end{array}$ & $\begin{array}{l}\text { 6.1. Berkomunikasi secara efektif, empati dan santun } \\
\text { terhadap anak } \\
\text { 6.2. Bersikap sopan sesuai dengan norma } \\
\text { 6.3. Berpenampilan rapih, menarik dan ceria }\end{array}$ \\
\hline
\end{tabular}

\section{Desain Kurikulum Program Profesi Guru PAUD}

\section{A.Struktur Kurikulum}


Struktur kurikulum program PPG berisi program pengemasan materi bidang studi untuk pembelajaran yang mendidik (subject specific pedagogy) SSP, dan Praktik Pengalaman Lapangan (PPL). SSP adalah suatu kegiatan pembelajaran dalam bentuk lokakarya atau workshop. PPL adalah pemberian pengalaman langsung pembelajaran dan pendidikan di lembaga mitra.

Beban belajar yang harus diselesaikan peserta PPG PAUD adalah sebagai berikut:
1. Bagi luluan S1 PGPAUD / PGTK sebanyak 20 SKS dengan rincian;

a) Workshop SSP (subject specific pedagogy) $6 \mathrm{SKS}$

b) Pemantapan Program Pengalaman Lapangan (PPL) 14 SKS.

2. Bagi lulusan S1 non PGPAUD / PGTK sebanyak 40 SKS dengan rincian;

a) Workshop SSP (subject specific pedagogy) 20 SKS

b) Pemantapan Program Pengalaman Lapangan (PPL) 20 SKS.

Tabel 2.1

Struktur Kurikulum PPG PAUD

\begin{tabular}{|c|c|l|l|c|c|}
\hline \multirow{2}{*}{ No } & \multirow{2}{*}{ Kode } & $\begin{array}{c}\text { Perkuliahan/ } \\
\text { Kegiatan } \\
\text { Akademik }\end{array}$ & \multicolumn{1}{c|}{ Kegiatan } & \multicolumn{2}{c|}{ SKS } \\
\cline { 3 - 5 } & & $\begin{array}{l}\text { Subject Specific } \\
\text { Paedagogy (SSP) }\end{array}$ & & S1 & $\begin{array}{c}\text { S1 NON } \\
\text { PGPAUD }\end{array}$ \\
\hline 1 & & $\begin{array}{l}\text { Workshop } \\
\text { pengembangan } \\
\text { Kurikulum }\end{array}$ & $\begin{array}{l}\text { Peserta PPG membuat program } \\
\text { kegiatan secara utuh untuk } \\
\text { kelompok usia tertentu sesuai } \\
\text { dengan kebutuhan dan } \\
\text { perkembangan anak }\end{array}$ & 2 & \\
\hline 2 & & $\begin{array}{l}\text { Workshop } \\
\text { Pengembangan } \\
\text { Pembelajaran AUD }\end{array}$ & $\begin{array}{l}\text { Peserta PPG-PAUD membuat } \\
\text { perangkat pembelajaran anak usia } \\
\text { dini, yang terdiri atas RPP, bahan, } \\
\text { Media, dan penataan lingkungan } \\
\text { pembelajaran }\end{array}$ & 2 & 4 \\
\hline 3 & $\begin{array}{l}\text { Workshop } \\
\text { Pengemasan } \\
\text { Asesmen dan } \\
\text { Perkembangan }\end{array}$ & $\begin{array}{l}\text { Peserta PPG-PAUD membuat } \\
\text { instrumen asesmen } \\
\text { perkembangan anak usia dini }\end{array}$ & 1 & 10 \\
\hline
\end{tabular}




\begin{tabular}{|c|c|c|c|c|}
\hline & AUD & & & \\
\hline \multirow[t]{2}{*}{4} & Micro Teaching & $\begin{array}{l}\text { Peserta PPG-PAUD } \\
\text { Melaksanakan pembelajaran bagi } \\
\text { anak usia dini antar teman sejawat }\end{array}$ & 1 & 2 \\
\hline & $\begin{array}{c}\text { Program } \\
\text { Pengalaman } \\
\text { Lapangan }(\mathrm{PPL}\end{array}$ & & & \\
\hline 5 & PPL & $\begin{array}{l}\text { Peserta PPG-PAUD } \\
\text { melaksanakan kegiatan } \\
\text { pembelajaran untuk } \\
\text { mengembangkan aspek-aspek } \\
\text { perkembangan anak secara utuh, } \\
\text { terpadu, kontekstual, bermakna, } \\
\text { dan menyenangkan melalui } \\
\text { kegiatan bermain }\end{array}$ & 12 & 18 \\
\hline 6 & $\begin{array}{l}\text { Penelitian Tindakan } \\
\text { Kelas }\end{array}$ & $\begin{array}{l}\text { Melakukan refleksi terhadap } \\
\text { proses, hasil PPL yang telah } \\
\text { dilakukan dan merancang } \\
\text { peningkatan pembelajaran secara } \\
\text { berkelanjutan }\end{array}$ & 2 & 2 \\
\hline \multicolumn{3}{|c|}{ TOTAL } & 20 & 40 \\
\hline
\end{tabular}

\section{B.Pemetaan Struktur Kurikulum PPG PAUD UPI}

Pemetaan struktur kurikulum PPG PAUD UPI dikembangkan berdasarkan struktur kurikulum PPG PAUD. Pemetaan tersebut esensinya berfokus pada keempat kompetensi yang harus dimiliki oleh guru seperti yang telah dijelaskan dalam paparan di atas, yaitu kompetensi pedagogik, kepribadian, sosial, dan kompetensi profesional.

\section{Kompetensi Pedagogik}

Kompetensi pedagogik yaitu kemampuan yang harus dimiliki guru TamanKanak-Kanak berkenaan dengan karakteristik peserta didik dilihat dari berbagai aspek seperti fisik, moral, sosial, kultural, emosional, dan intelektual. Hal tersebut berimplikasi bahwa seorang guru Taman Kanak-Kanak harus mampu menguasai teori perkembangan dan prinsipprinsip pembelajaran yang mendidik karena anak sebagai peserta didik memiliki karakter, sifat, dan interes yang berbeda.

Selain itu seorang guru harus mampu mengembangkan kurikulum di tingkat satuan pendidikan dan disesuaikan dengan kebutuhan lokal. Guru harus mampu mengoptimalkan potensi anak sebagai peserta didik untuk mengaktualisasikan kemampuannya di kelas atau di lingkungan belajar lainnya, dan harus mampu melakukan penilaian terhadap kegiatan pembelajaran yang telah dilakukan. Kemampuan yang harus dimiliki guru berkenaan dengan aspek-aspek yang diamati, yaitu: a. Penguasaan terhadap karakteristik peserta didik dari aspek fisik, moral, sosial, kultural, emosional dan intelektual. b. Penguasaan terhadap teori 
perkembangan dan prinsip-prinsip pembelajaran yang mendidik. c. Mampu mengembangkan kurikulum yang terkait dengan bidang pengembangan yang diampu. d. Menyelenggarakan kegiatan pengembangan yang mendidik. e. Memanfaatkan teknologi informasi dan komunikasi untuk kepentingan penyelenggaraan kegiatan pengembangan yang mendidik. f. Memfasilitasi pengembangan potensi peserta didik untuk mengaktualisasikan berbagai potensi yang dimiliki. g. Berkomunikasi secara efektif, empatik, dan santun dengan peserta didik. $h$. Melakukan penilaian dan evaluasi proses dan hasil belajar, memanfaatkan hasil penilaian dan evaluasi untuk kepentingan pembelajaran. i. Melakukan tindakan reflektif untuk peningkatan kualitas pembelajaran.

\section{Kompetensi Kepribadian}

Pelaksanaan tugas sebagai guru harus didukung oleh suatu perasaan bangga akan tugas yang dipercayakan kepadanya untuk mempersiapkan kualitas generasi emas masa depan. Walaupun berat tantangan dan rintangan yang dihadapi dalam pelaksanaan tugas, guru harus tetap tegar dalam melaksakan tugas sebagai seorang pendidik. Pendidikan adalah proses yang direncanakan agar semua berkembang melalui proses pembelajaran. Guru sebagai pendidik harus dapat mempengaruhi ke arah proses itu sesuai dengan tata nilai yang dianggap baik dan berlaku dalam masyarakat. Tata nilai termasuk norma, moral, estetika, dan ilmu pengetahuan, mempengaruhi perilaku etik peserta didik sebagai pribadi dan sebagai anggota masyarakat. Penerapan disiplin yang baik dalam proses pendidikan akan menghasilkan sikap mental, watak dan kepribadian peserta didik yang kuat. Guru dituntut harus mampu membelajarkan peserta didiknya tentang disiplin diri, belajar membaca, mencintai buku, menghargai waktu, belajar bagaimana cara belajar, mematuhi aturan/tata tertib, dan belajar bagaimana harus berbuat. Semuanya itu akan berhasil apabila guru juga disiplin dalam melaksanakan tugas dan kewajibannya. Guru harus mempunyai kemampuan yang berkaitan dengan kemantapan dan integritas kepribadian seorang guru. Aspek-aspek yang diamati adalah: a. Bertindak sesuai dengan norma agama, hukum, sosial, dan kebudayaan nasional Indonesia. b. Menampilkan diri sebagai pribadi yang jujur, berakhlak mulia, dan teladan bagi peserta didik dan masyarakat. c. Menampilkan diri sebagai pribadi yang mantap, stabil, dewasa, arif, dan berwibawa. d. Menunjukan etos kerja, tanggung jawab yang tinggi, rasa bangga menjadi guru, dan rasa percaya diri.

\section{Kompetensi Sosial}

Guru di mata masyarakat dan peserta didik merupakan panutan yang perlu dicontoh dan merupkan suri tauladan dalam kehidupanya sehari-hari. Guru perlu memiliki kemampuan sosial dengan masyarakat, dalam rangka pelaksanaan proses pembelajaran yang efektif. Dengan kemampuan tersebut, otomatis hubungan sekolah dengan masyarakat akan berjalan dengan lancar, sehingga jika ada keperluan dengan orang tua peserta didik, para guru tidak akan mendapat kesulitan. Kemampuan sosial meliputi kemampuan guru dalam berkomunikasi, bekerja sama, bergaul simpatik, dan mempunyai jiwa yang menyenangkan. Kriteria kinerja guru dalam kaitannya dengan kompetensi sosial disajikan berikut ini. a. Bertindak objektif serta tidak diskriminatif karena pertimbangan jenis kelamin, agama, ras, kondisi fisik, latar belakang keluarga, dan status sosial ekonomi. b. Berkomunikasi secara efektif, empatik, dan santun dengan sesama pendidik, tenaga kependidikan, orang tua, dan masyarakat. c. Beradaptasi di tempat bertugas di seluruh wilayah 
Republik Indonesia yang memiliki keragaman sosial budaya. d. Berkomunikasi dengan komunitas profesi sendiri dan profesi lain secara lisan dan tulisan atau bentuk lain.

\section{Kompetensi Profesional}

Kompetensi profesional yaitu kemampuan yang harus dimiliki guru dalam perencanaan dan pelaksanaan proses pembelajaran. Guru mempunyai tugas untuk mengarahkan kegiatan belajar peserta didik untuk mencapai tujuan pembelajaran. Untuk itu guru dituntut mampu menyampaikan bahan pelajaran. Guru harus selalu mengupdate, dan menguasai materi pelajaran yang disajikan. Persiapan diri tentang materi diusahakan dengan jalan mencari informasi melalui berbagai sumber seperti membaca buku-buku terbaru, mengakses dari internet, selalu mengikuti perkembangan dan kemajuan terakhir tentang materi yang disajikan. Dalam menyampaikan pembelajaran, guru mempunyai peranan dan tugas sebagai sumber materi yang tidak pernah kering dalam mengelola proses pembelajaran. Kegiatan mengajarnya harus disambut oleh peserta didik sebagai suatu seni pengelolaan proses pembelajaran yang diperoleh melalui latihan, pengalaman, dan kemauan belajar yang tidak pernah putus. Keaktifan pesertadidik harus selalu diciptakan dan berjalan terus dengan menggunakan metode dan strategi mengajar yang tepat. Guru menciptakan suasana yang dapat mendorong pesertadidik untuk bertanya, mengamati, mengadakan eksperimen, serta menemukan fakta dan konsep yang benar. Karena itu guru harus melakukan kegiatan pembelajaran menggunakan multimedia, sehingga terjadi suasana belajar sambil bekerja, belajar sambil mendengar, dan belajar sambil bermain, sesuai kontek materinya. Guru harus memperhatikan prinsip-prinsip didaktik metodik sebagai ilmu keguruan. Misalnya, bagaimana menerapkan prinsip apersepsi, perhatian, kerja kelompok, dan prinsip-prins ip lainnya.

Dalam hal evaluasi, secara teori dan praktik, guru harus dapat melaksanakan evaluasi atau penilaian sesuai dengan tujuan yang ingin diukurnya. Jenis penilaian yang digunakan untuk mengukur hasil belajar harus benar dan tepat. Diharapkan pula guru dapat menyusun instrument penilaian secara benar, agar instrumen yang dibuat dapat digunakan untuk memperoleh gambaran perkembangan anak yang sesungguhnya. Kemampuan yang harus dimiliki pada dimensi kompetensi profesional atau akademik dapat diamati dari aspek-aspek berikut ini. a. Menguasai materi, struktur, konsep, dan pola pikir keilmuan yang mendukung mata pelajaran yang diampu. $b$. Menguasai standar kompetensi dan kompetensi dasar mata pelajaran/ bidang pengembangan yang diampu. c. Mengembangkan materi pelajaran yang diampu secara kreatif. d. Mengembangkan keprofesian secara berkelanjutan dengan melakukan tindakan reflektif e. Memanfaatkan teknologi informasi dan komunikasi untuk berkomunikasi dan mengembangkan diri.

\section{PENUTUP}

1. Proses menjadi guru profesional ditempuh melalui pendidikan akademik dan pendidikan profesi. Proses tersebut bermuara pada peningkatan pengetahuan dan keterampilan mengajar melalui tiga hal berikut: (1) transfer pengalaman mengajar dalam seting otentik, (2) pemaduan teori dan praktik learning to teach dalam konteks practice in practice dan (3) berlangsung secara kolaboratif di dalam komunitas profesional.

2. Pembinaan dan pengembangan profesi guru dilakukan melalui program pembinaan dan pengembangan profesi yang dalam hal ini adalah Pendidikan 
PEDAGOGIA : Jurnal Ilmu Pendidikan

Profesi Guru. berdasarkan studi kebutuhan guru di lapangan, kebutuhan esensi pembinaan profesi beragam sifatnya. Kebutuhan dimaksud dikelompokkan ke dalam lima kategori, yaitu pemahaman tentang konteks pembelajaran, penguatan penguasaan materi, pengembangan metode mengajar, inovasi pembelajaran, dan pengalaman tentang teori-teori terkini.

3. Pemetaan struktur kurikulum PPG PAUD dikembangkan berdasarkan struktur kurikulum PPG PAUD. Pemetaan tersebut esensinya berfokus pada keempat kompetensi yang harus dimiliki oleh guru, yaitu kompetensi pedagogik, kepribadian, sosial, dan kompetensi profesional.

\section{DAFTAR PUSTAKA}

Hamalik, Oemar. (2004). Pendidikan Guru Berdasarkan Pendekatan Kompetensi. Jakarta : Bumi Aksara
Jalal, Fasli (2002). Pendidikan Anak Usia Dini Pendidikan yang Mendasar. Jurnal Ilmiah Anak Dini Usia. Vol.03 Hal.4-8.

Mulyasa, E. (2006). Menjadi Guru Profesional Menciptakan Pembelajaran Kreatif dan Menyenangkan. Bandung : Remaja Rosdakarya

Masnifal, (2013). Siap Menjadi Guru dan Pengelola PAUD Profesional (Pijakan Mahasiswa, Guru dan Pengelola TK/RA/KB/TPA). PT Elex Media Komputindo : Jakarta

Sugiyono, (2005). Memahami Penelitian Kualitatif. Bandung : Alfabeta.

Usman Uzer, (2004). Menjadi Guru Profesional. Remaja Rosdakarya; Bandung. 